\title{
Droneflies (Diptera: Syrphidae) occurring from manure and effluent of manure in Hokkaido, Japan
}

\author{
Hitoshi Sasaki and Akiko Mikami \\ Laboratory of Environmental Entomology, Rakuno Gakuen University, \\ 582 Bunkyodai-Midorimachi, Ebetsu, Hokkaido, 069-8501 Japan
}

(Received: 28 December 2006; Accepted: 16 March 2007)

\begin{abstract}
A total of 566 individuals of droneflies belonging to 3 genera and 5 species emerged from manure and effluent of manure as a breeding media in Ebetsu and Shizunai, Hokkaido, Japan. Of these species, Eristalis (Eoseristalis) cerealis Fabricius was the predominant species, followed by Eristalis (Eristalis) tenax (Linnaeus), Helophilus (Helophilus) virgatus Coquillett, Eristalis (Eoseristalis) rossica Stackelberg and Eristalinus (Lathyrophthalmus) tarsalis (Macquart). The eggs of the five species examined showed little differences, but the units on the egg shell surface of $H$. virgatus were glabrous and differed from the other four excavation formed species. It was determined that the shape, arrangement and number of sensilla, proleg, crochets, spine of 7 th proleg and lappets are the useful characteristics for identifying the 3rd instar larvae. Distinct differences were observed on the shape of the anterior spiracles, and the shape and length of thoracic respirator process in pupae. A key to the 3rd instar larvae of dronefly species occurring from the effluent of manure in Hokkaido is provided.
\end{abstract}

Key words: dronefly, effluent of manure, manure, oviposition trap, Hokkaido, Japan

\section{INTRODUCTION}

The larvae of droneflies are regarded as harmful insects that cause myiasis in humans and livestock (Aguilera et al., 1999), and from the viewpoint of medical and veterinary entomology, nuisance insects because of their odd-looking long tailed shape. However, from the viewpoint of environmental and agricultural entomology, they are very important agents in decomposing manure, and in addition, their adults usually visit various flowers and act as pollinators (Goubara and Takasaki, 2003; Jarlan et al., 1997; Ohsawa and Namai, 1987).

Up to the present, knowledge about these droneflies and their association with animal husbandry in Japan is not well known. In the present study, we made investigations to determine the dronefly species occurring from effluent of manure, and the morphorogical characteristics of the immature stages of the flies were examined in order to obtain the basic information for effectual management of manure in Hokkaido, Japan.

\section{Materials And Methods}

The investigations were carried out at the Experimental Farm of Rakuno Gakuen University, Ebetsu, Hokkaido, Japan and the Experimental Farm of the Field Science Center for Northern Biosphere, Hokkaido University, Shizunai, Hokkaido, Japan in 1999 and 2000.

Oviposition traps were used for collecting the droneflies occurring from manure and effluent of manure. The media prepared for the oviposition trap in this in- 
vestigation was a mixture of 3.4 litters of artificial manure made of directly sampled cow dung from cow archo and fine cut hay $(1: 2)$ dissolved in 2.0 litters of water. The media was placed into plastic containers $(30 \mathrm{cmW} \times 30 \mathrm{cmL} \times 25 \mathrm{cmD})$ and the containers (oviposition traps) were left beside the compost depot for two weeks without any cover. The traps were then covered with an emergence cage equipped with a wire netted collecting container to capture the emerging adult droneflies. The species of the captured droneflies were identified, and their numbers were recorded.

Gravid female of the droneflies which occur from the oviposition trap were collected at the compost depot and were let to oviposit to the manure in the laboratory. The obtained eggs were reared to adults under room temperature conditions. Some eggs were preserved with $70 \%$ ethanol for observation by a scanning electron microscope. A part of the third instar larvae and pupae were also killed with hot water and preserved with 70\% ethanol for observation by scanning
Table 1. Droneflies occurred from oviposition traps.

\begin{tabular}{lrrrr}
\hline \hline \multirow{2}{*}{ Species } & \multicolumn{2}{c}{ Ebetsu } & & Shizunai \\
\cline { 2 - 3 } E. cerealis & 1999 & 2000 & & 2000 \\
E. rossica & 120 & 139 & 258 \\
E. tenax & 0 & 0 & 11 \\
E. tarsalis & 3 & 0 & 0 \\
H. virgatus & 1 & 0 & 0 \\
\cline { 1 - 2 } Total & 142 & 0 & 16 \\
\hline
\end{tabular}

electron and binocular microscopes.

\section{RESUlts}

Three genera and 5 species, totaling 566 individuals of droneflies emerged from manure and effluent of manure. Of these species, Eristalis (Eoseristalis) cerealis Fabricius was the most predominant species (517 flies, 91.3\%), followed by Eristalis (Eristalis) tenax (Linnaeus) (18 flies, 3.2\%), and the rest were Eristalinus (Lathyrophthalmus) tarsalis (Macquart), Helophilus

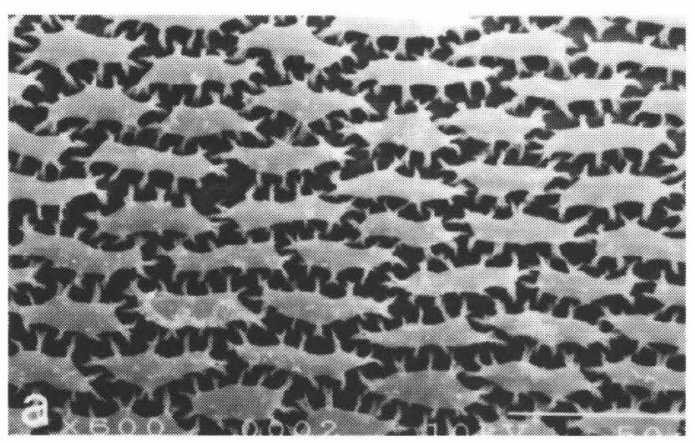

Fig. 1. Form of units on the egg shell, SEM photos. bar: $50 \mu \mathrm{m}$. a, Helophilus (Helophilus) virgatus (glabrous); b, Eristalis (Eoseristalis) cerealis (excavation).

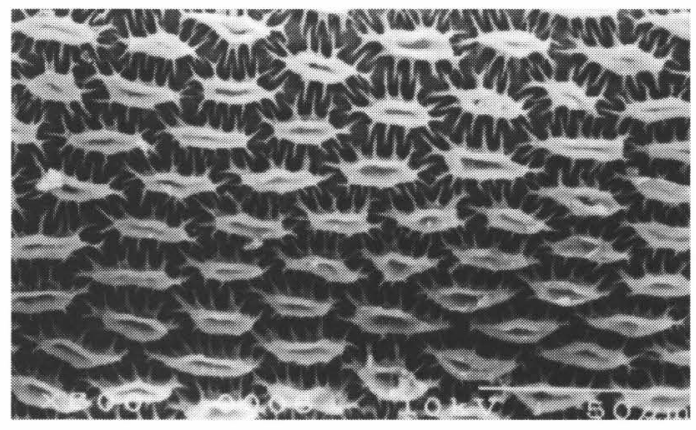

Table 2. Main morphological characters of eggs of droneflies examined.

\begin{tabular}{lccccc}
\hline \hline Character & E. cerealis & E. rossica & E. tenax & E. tarsalis & H. virgatus \\
\hline Length $(n=20)$ & $1.50 \pm 0.56 \mathrm{~mm}$ & $1.90 \pm 0.13 \mathrm{~mm}$ & $1.60 \pm 0.04 \mathrm{~mm}$ & $0.99 \pm 0.02 \mathrm{~mm}$ & $1.35 \pm 0.07 \mathrm{~mm}$ \\
& $(1.47-1.54)$ & $(1.68-2.06)$ & $(1.53-1.72)$ & $(0.96-1.02)$ & $(1.20-1.47)$ \\
Maximum width & $0.50 \pm 0.34 \mathrm{~mm}$ & $0.51 \pm 0.03 \mathrm{~mm}$ & $0.47 \pm 0.02 \mathrm{~mm}$ & $0.29 \pm 0.01 \mathrm{~mm}$ & $0.46 \pm 0.04 \mathrm{~mm}$ \\
& $(0.39-0.43)$ & $(0.47-0.56)$ & $(0.43-0.50)$ & $(0.29-0.31)$ & $(0.40-0.55)$ \\
Form of units & excavation & excavation & excavation & excavation & glabrous \\
\hline
\end{tabular}



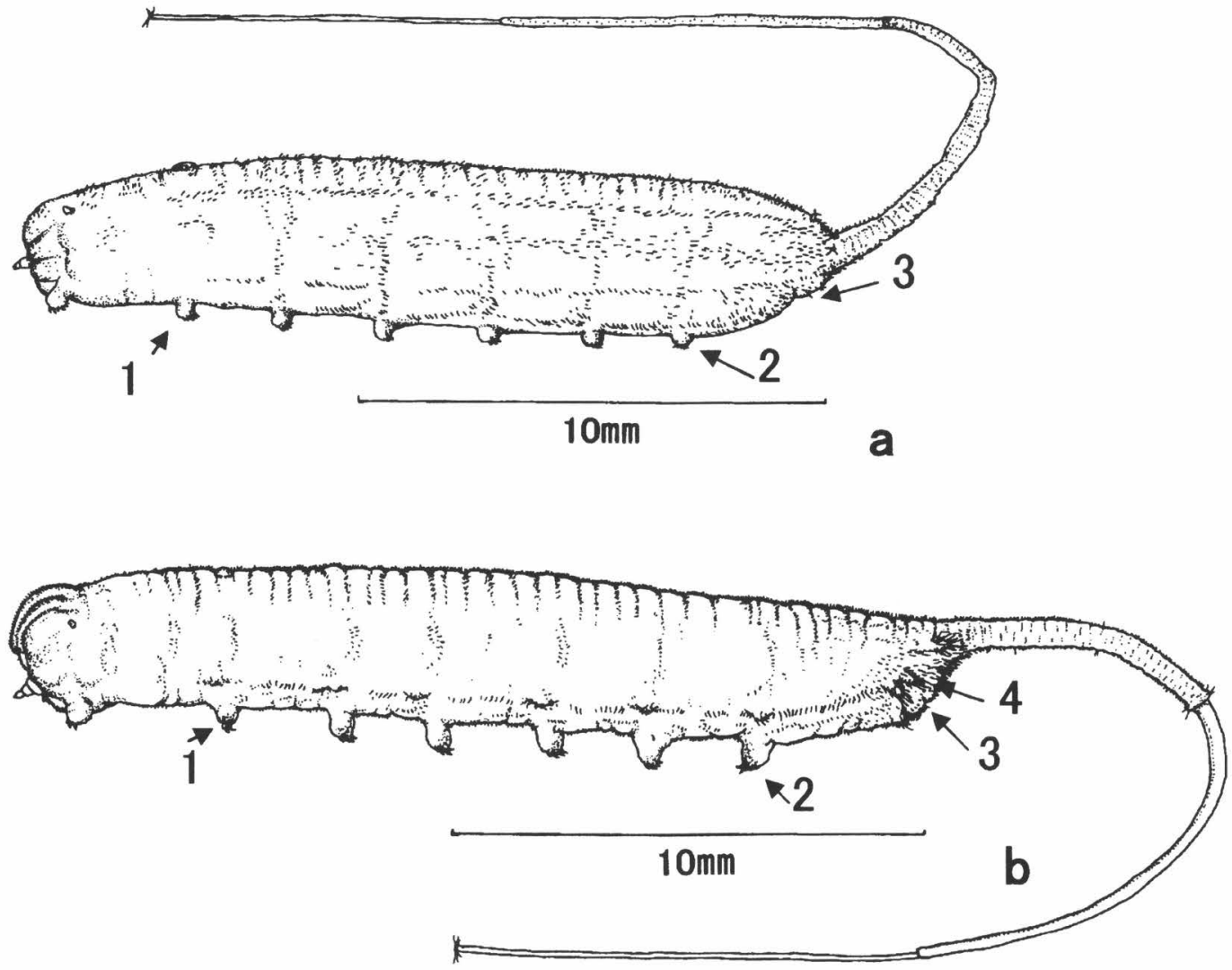

Fig. 2. Third instar larvae of droneflies, lateral view. a, Eristalis (Eoseristalis) cerealis; b, Helophilus (Helophilus) virgatus. 1, Second abdominal proleg; 2, Seventh abdominal proleg; 3, Anal segment; 4, lappets of the anal segment.
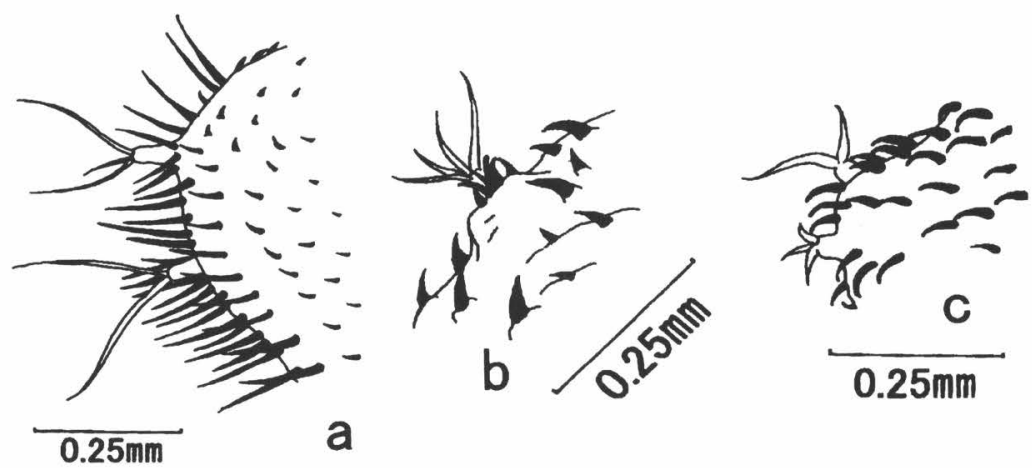

Fig. 3. Sensillae on the anal segments of the 3rd instar larvae. a, Helophilus (Helophilus) virgatus; b, Eristalis (Eoseristalis) rossica; c, Eristalis (Eristalis) tenax.

(Helophilus) virgatus Coquillett and Eristalis (Eoseristalis) rossica Stackelberg (Table 1).

The eggs of the five species examined showed little difference in length and width, and these differences were not significant among the species. The units on the egg shell surface (Kuznetzov, 1988) of 

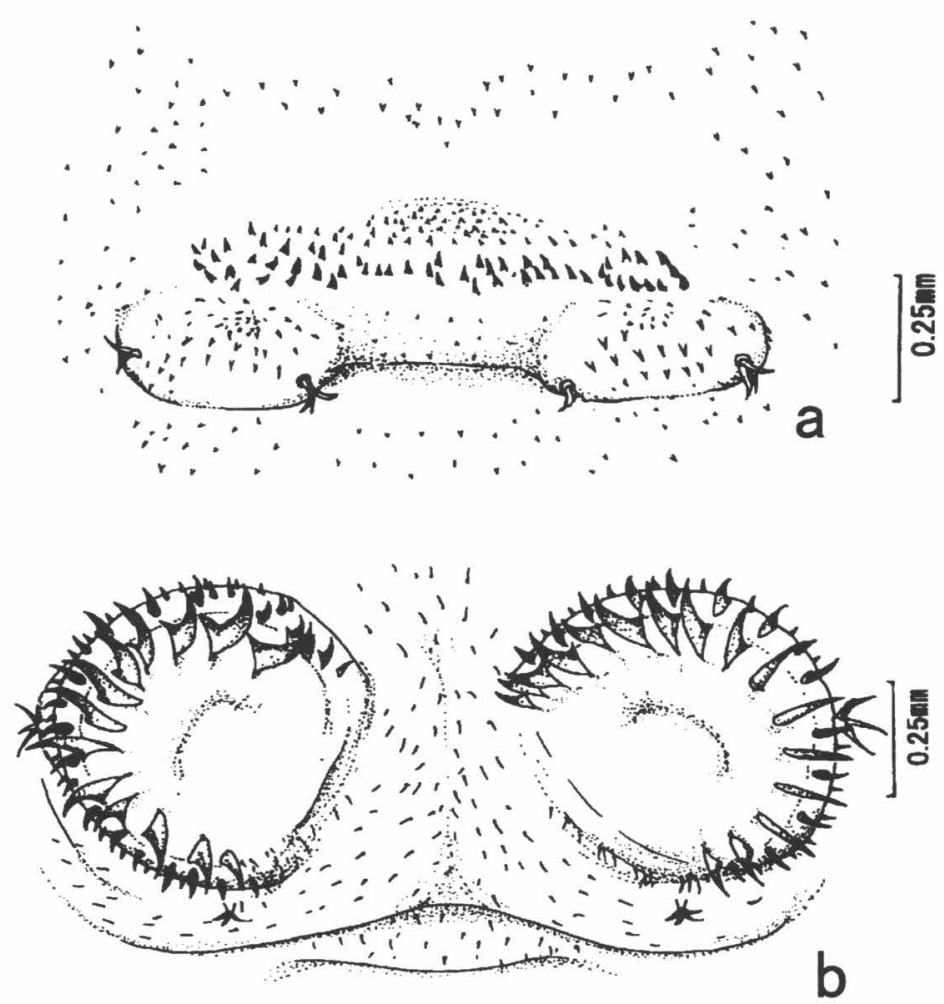

Fig. 4. Seventh abdominal prolegs of 3rd instar larvae. Ventral view. a, Eristalinus (Lathyrophthalmus) tarsalis; b, Helophilus (Helophilus) virgatus.

H. virgatus were glabrous and differed from the other four excavation formed species (Fig. 1). The morphological characters of the $E$. cerealis and $E$. tenax eggs were too similar to differentiate the two species (Table 2).

It was determined that the shape, arrangement and number of sensilla of anal segments (Figs. 2 and 3), seventh abdominal proleg (Figs. 2 and 4), crochets of 2 nd proleg (Figs. 2 and 5), spines of 7 th proleg (Figs. 2 and 4) and lappets of anal segments (Figs. 2 and 6) are the useful characteristics for identifying the 3rd instar larvae of the five species examined (Table 2). The ventral pharyngeal ridge, the typical organ of detrivorous species (Whittington, 1994), was observed in all five species (Fig. 7).

The differences in the shape of the anterior spiracles of larvae (Fig. 8), and the shape and length of thoracic respirator process in the pupae (Fig. 9) of the five species examined (Table 3 ) were observed in detail.

A key to the 3rd instar larvae is prepared based on the results obtained in this study.

\section{Key to the species of 3rd instar larvae of droneflies occurring from manure and effluent of manure in Hokkaido, Japan}

1. Straight trachea visible through the skin (Fig. 10b) ............................2

- Wavy trachea visible through the skin (Fig. 10a) . Helophilus (Helophilus) virgatus Coquillett

2. Seventh abdominal prolegs with 3 to 4 rows of distinct spines (Fig. 4a); anterior spiracle octopus leg-like shaped (Fig. 8a). 


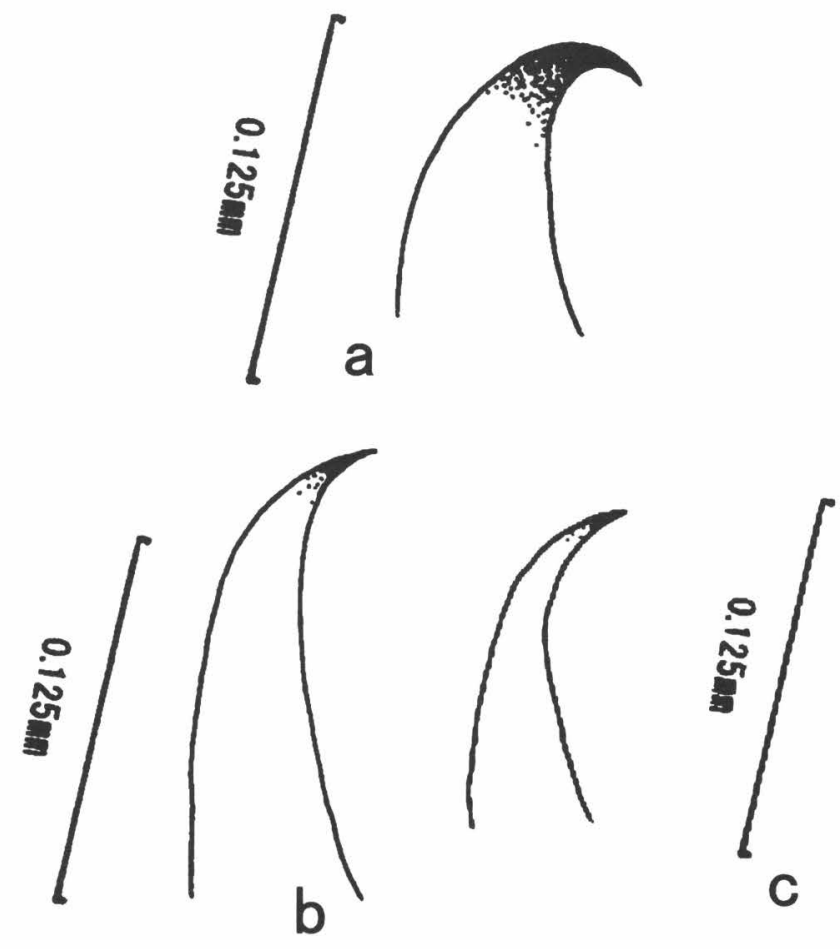

Fig. 5. Crochets of 2nd abdominal prolegs of 3rd instar larvae. a, Eristalis (Eristalis) tenax; b, Eristalis (Eoseristalis) rossica; c, Eristalis (Eoseristalis) cerealis.

\section{Eristalinus (Lathyrophthalmus) tarsalis (Macquart)}

- Seventh abdominal prolegs without such spine rows (Fig. 4b); anterior spiracle not octopus leg-like shaped (Fig. 8b)

\section{3}

3. Sensilla on the anal segment setaelike shaped (Fig. 3a, c) .4

- Sensilla on the anal segment spinelike shaped, not setae (Fig. 3b)

Eristalis (Eoseristalis) rossica

Stackelberg

4. Primary crochets of 2nd abdominal proleg gently folded (Fig. 5b); anterior spiracle mitten shaped (Fig. 8c)....

Eristalis (Eoseristalis) cerealis Fabricius

- Primary crochets of 2nd abdominal proleg sharply folded (Figs. 5a and c); anterior spiracle egg shaped (Fig. 8d) Eristalis (Eristalis) tenax

(Linnaeus)

\section{Discussion}

In the present study, five dronefly species belonging to the genera Eristalis, Eristalinus and Helophilus were identified to occur from manure and effluent of manure, a very polluted liquid, in Hokkaido, Japan. However, Thompson and Rotheray (1998) reported that Eristalinus species mainly occur from the clean water of ponds such as irrigation pond or marshes. Furthermore, Ikezaki (1999) mentioned that the breeding site of the Helophilus species to be a clean water pool floating scum. Breeding site of these reports differed from our results, however, we concluded that many Eristalinus and Helophilus species visit and oviposit their eggs in manure at compost depots.

As a result of the morphological observations, it is very difficult to identify eggs by morphological characters, but in the 

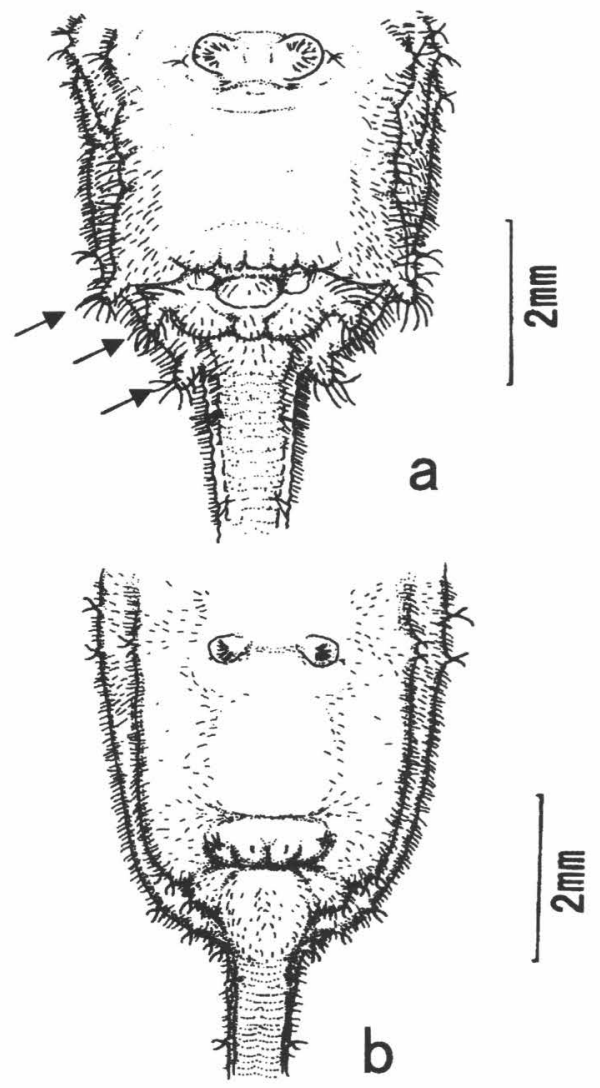

Fig. 6. Anal segment of 3rd instar larvae, ventral view. $f$ shows the lappets. a, Helophilus (Helophilus) virgatus; b, Eristalis (Eoseristalis) cerealis. 3rd instar larvae and pupae, it was easy to differentiate the species. The spine rows of the 7 th prolegs, which were mentioned as a generic character of Helophilus and Eristalinus by Thompson and Rotheray (1998) were observed only on E. tarsalis but not on $H$. virgatus in this study (Fig. 4). Further examination is required to confirm whether the discrepancies between this study and the other observations are a special case or not.

Some characters of puparium such as shape and length of anterior spiracle (Fig. 11 ), and the thoracic respiratory process are determined to be useful characteristics for identifying the five dronefly species (Table 4). Among them, the shape of anterior spiracles is determined to be the most useful one. This result was agree with studies of Kuznetzov and Kuznetzova (1994, 1995).

In view of the results of this study, the effluent of manure is one of a breeding source of droneflies in Japan, and the morphological characters of their immature stages were useful for determining species. The knowledge obtained in this study must contribute to farm management, especially compost management.

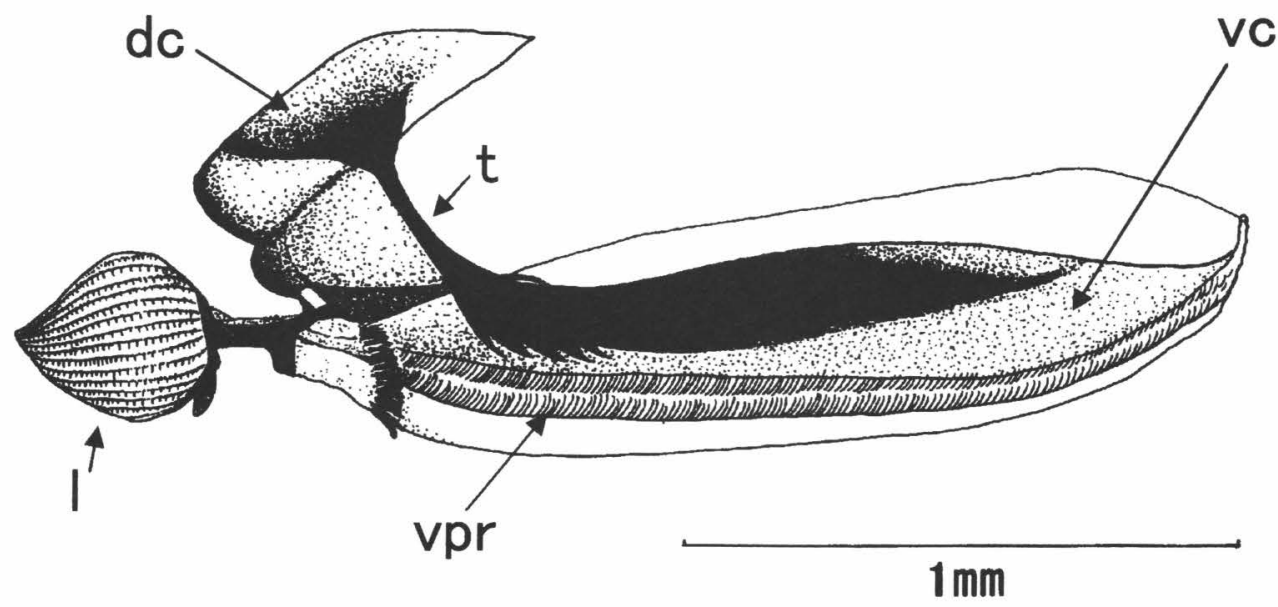

Fig. 7. Cephalopharyngeal skeleton of Eristalis (Eoseristalis) cerealis, lateral view. 1, mandibular lobe; $\mathrm{dc}$, dorsal cornu; t, tentorium; vc, ventral cornu; vpr, ventral pharyngeal ridges. 

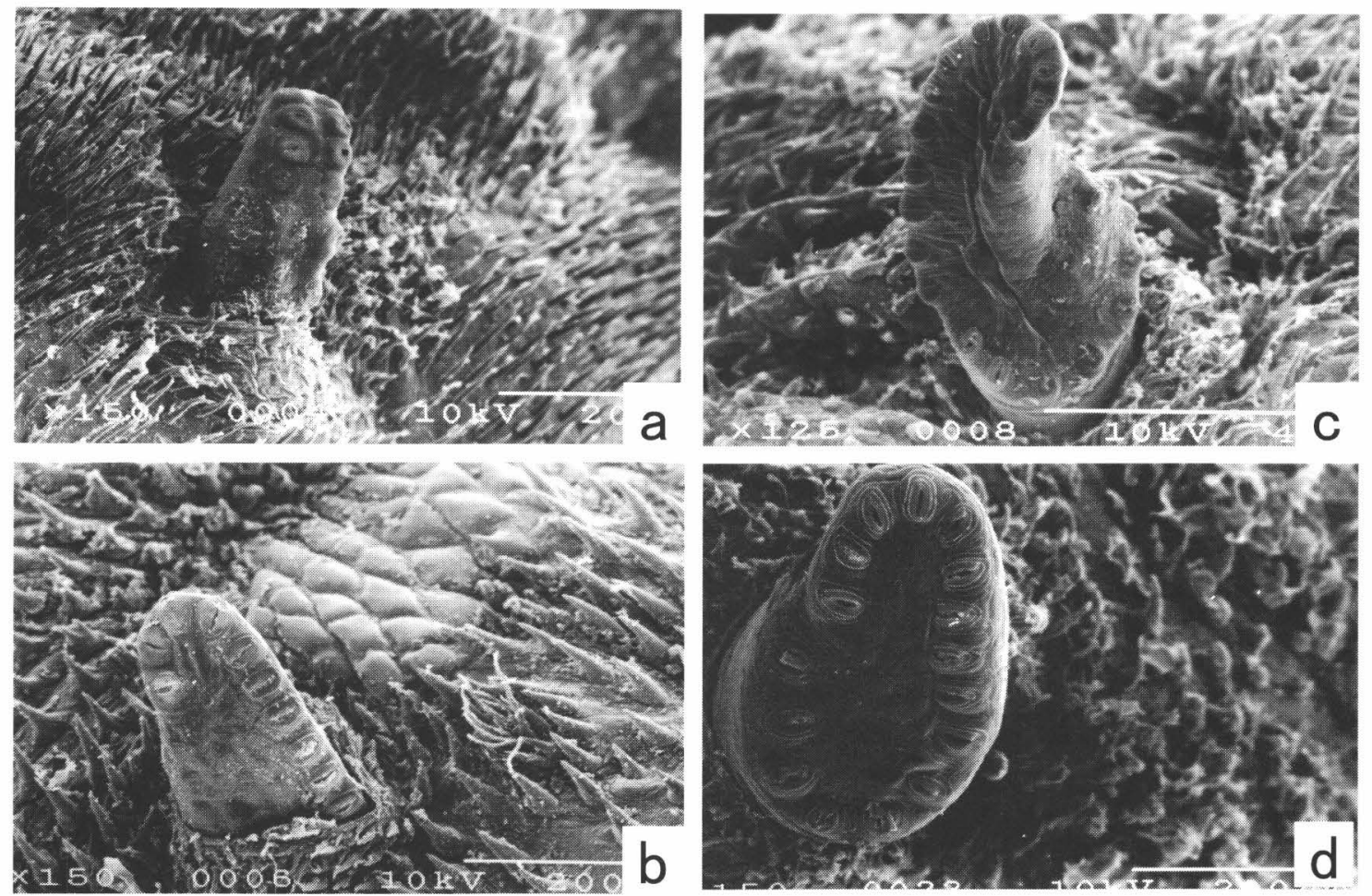

Fig. 8. Anterior spiracles of 3rd instar larvae, SEM photos. a, Eristalinus (Lathyrophthalmus) tarsalis; b, Eristalis (Eoseristalis) rossica; c, Eristalis (Eoseristalis) cerealis; d, Eristalis (Eristalis) tenax.
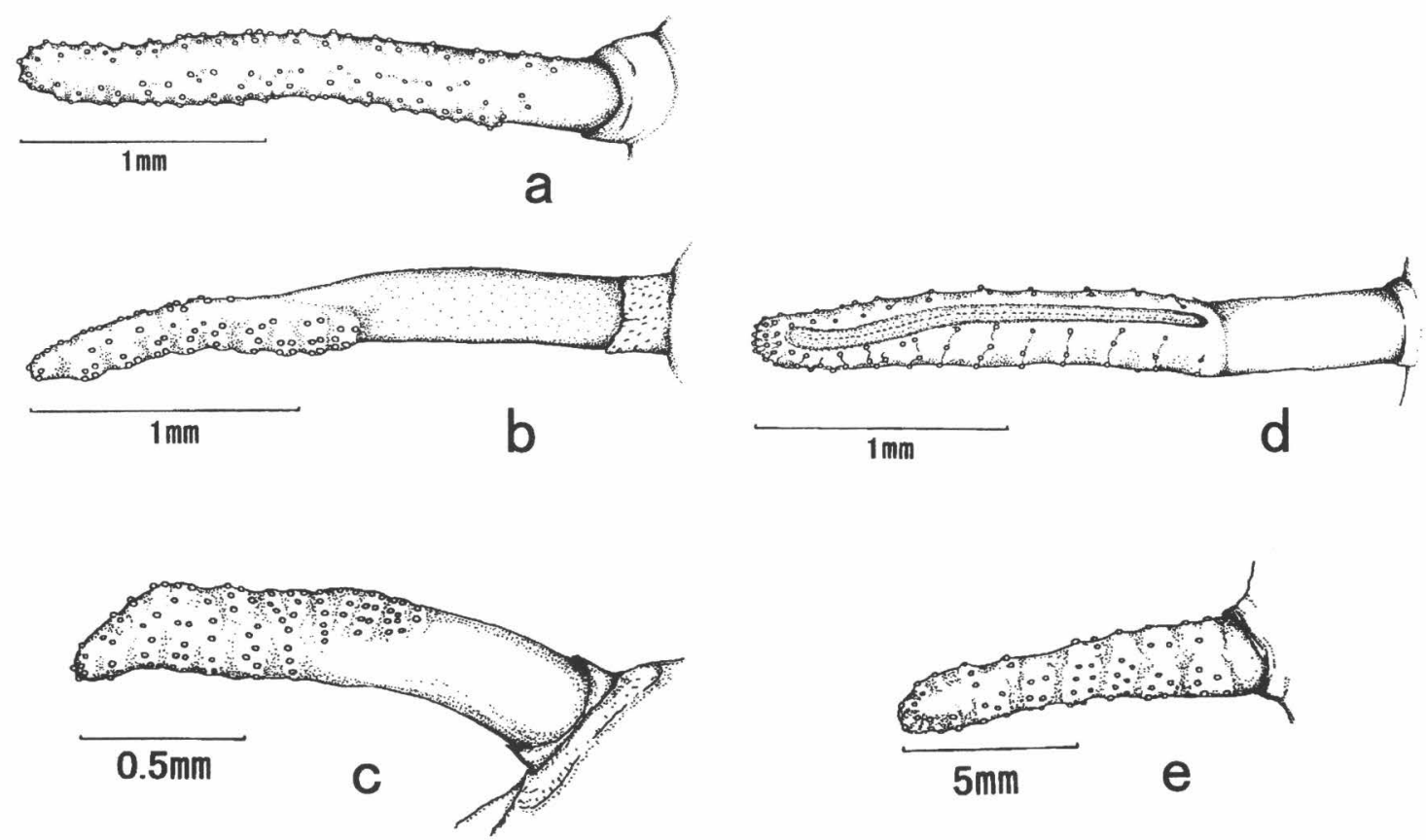

Fig. 9. Thoracic respiratory processes of pupae. a, Eristalis (Eoseristalis) cerealis; b, Eristalis (Eoseristalis) rossica; c, Eristalis (Eristalis) tenax; d, Eristalinus (Lathyrophthalmus) tarsalis; e, Helophilus (Helophilus) virgatus. 
Table 3. Main morphological characters of 3rd instar larvae of droneflies examined.

\begin{tabular}{|c|c|c|c|c|c|}
\hline Character & E. cerealis & E. rossica & E. tenax & E. tarsalis & H. virgatus \\
\hline $\begin{array}{l}\text { Trachea shown through } \\
\text { the skin }\end{array}$ & straight & straight & straight & straight & wavy \\
\hline Sensilla & setae & spines & setae & $\begin{array}{l}\text { long spines and } \\
\text { short spines }\end{array}$ & setae \\
\hline Prolegs & developed & developed & developed & vestigial & developed \\
\hline Crochets & gently curved & gently curved & sharply curved & gently curved & gently curved \\
\hline Spine at 7 th proleg & absent & absent & absent & 3 to 4 rows & absent \\
\hline Lappets & absent & absent & absent & absent & 3 pairs \\
\hline
\end{tabular}
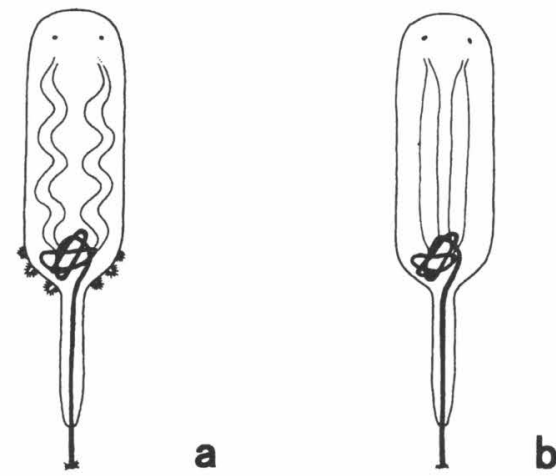

Fig. 10. Trachae shown through the skin. a, Helophilus (Helophilus) virgatus; b, Eristalis (Eoseristalis) rossica.
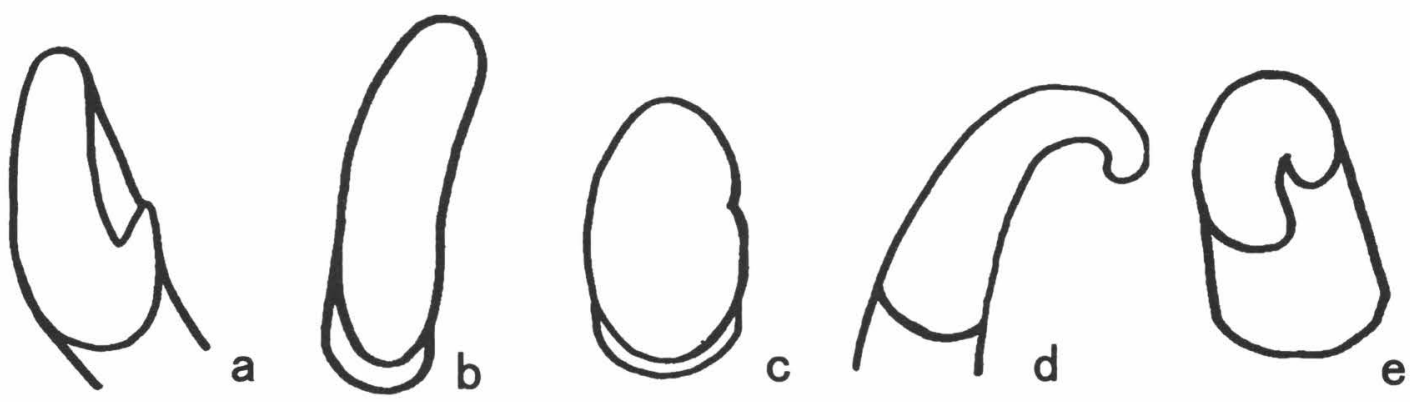

Fig. 11. Anterior spiracles of pupae. a, Eristalis (Eoseristalis) cerealis; b, Eristalis (Eoseristalis) rossica; c, Eristalis (Eristalis) tenax; d, Eristalinus (Lathyrophthalmus) tarsalis; e, Helophilus (Helophilus) virgatus.

Table 4. Main morphological characters of pupae of droneflies examined.

\begin{tabular}{llllll}
\hline \hline \multicolumn{1}{c}{ Character } & E. cerealis & E. rossica & E. tenax & E. tarsalis & H. virgatus \\
\hline $\begin{array}{l}\text { Anterior spiracles } \\
\begin{array}{c}\text { Thoracic respiratory } \\
\text { process }\end{array}\end{array}$ & mitten like & tongue like & egg like & octopus leg like & stump like \\
$\begin{array}{c}\text { Disc-shaped spiracular } \\
\text { openings }\end{array}$ & long & short & long & short \\
Body surface objects & setae & spines & setae & long spines & 3 parts lappets and setae \\
\hline
\end{tabular}




\section{REFERENCES}

Aguilera, A., Cid, A. and Regueiro, B. J. 1999. Intestinal myiasis caused by Eristalis tenax. J. Clin. Microbiol., 37: 3082.

Goubara, M. and Takasaki, T. 2003. Flower visitors of lettuce under field and enclosure conditions. Appl. Entomol. Zool., 38: 571-581.

Ikezaki, Y. 1999. Getting eggs and breeding long tailed larvae of Eristalini (Diptera: Syrphidae). Hana abu, 8: 13-14.

Jarlan, A., de Oliveira, D. and Gingras, J. 1997. Pollination by Eristalis tenax (Diptera: Syrphidae) and seed set of greenhouse sweet pepper. J. Econ. Entomol., 90: 1646-1649.

Kuznetzov, S. Y. 1988. Morphology of the egg of hover-flies (Diptera: Syrphidae). Entomol. Obozr., 67: 741-753.

Kuznetzov, S. Y. and Kuznetzova, N. V. 1994. Description of the unknown larvae and puparia of some aquatic Syrphidae (Diptera) species from the genera Neoascia, Chrysogaster, Orthonevra and Eristalis. Dipterological Research, 5: 271-287.

Kuznetzov, S. Y. and Kuznetzova, N. V. 1995. Description of the unknown larvae and puparia of some aquatic Syrphidae (Diptera) species from the genera Conosyrphus, Mallota and Myathropa. Dipterological Research, 6: 135-141.

Ohsawa, R. and Namai, H. 1987. The effect of insect pollinators on pollination and seed setting in Brassica campestris cv. Nozawana and Brassica juncea cv. Kikarashina. Jpn. J. Breed., 37: 453-463.

Thompson, F.C. and Rotheray, G. 1998. Family Syrphidae. In: Contribution to a Manual of Paraearctic Diptera (ed. Papp, L. and Darvas, B.), Vol. 3. pp. 81-139, Science Herald, Budapest.

Whittington, A. E. 1994. Description of the puparia of three Graptomyza species (Diptera Syrphidae), with comments on probable larval biology. Trop. Zool., 7: $57-65$. 